\title{
Higher Education Financing in Nepal
}

\author{
Keshar J. Baral
}

\begin{abstract}
National policy on the financing of higher education is to recover the recurrent costs and shift the burden of higher education to the private sector. This paper, using the financial data published by University Grants Commission (UGC) and extracted from the financial statements of Pokhara University (POKU), attempts to analyze the financing pattern of higher education in Nepal. In general, it analyzes the overall financing pattern of higher education in Nepal and in particular of POKU during the last eight fiscal years (FY 1999 through 2006). This concludes that the level of budget for higher education in Nepal is relatively low and not enough to bring up the accessibility of qualitative higher education. Moreover, it concludes that government grants-both administrative and development, provided to the universities are not consistent during the study period.
\end{abstract}

Key words: higher education, University Grants Commission, administrative grant, development grant

\section{Introduction}

History of tertiary education in Nepal dates back to 1918 in which year Tribhuvan Chandra Intermediate College was established. After five years, this college was converted into Trichandra College. This was the only college that used to impart the tertiary education in Nepal till 1950. After the dawn of democracy in Nepal in 1951, a number of Intermediate and Degree colleges were established within and outside the Kathmandu valley in the initiation of the then government and community (for detail of colleges, see All Nepal Education Committee, Reports, 1961). But there was no university in the country. So, all colleges were affiliated to Indian universities. Tribhuvan University (TU) was incorporated in 1958 on the recommendation of Nepal National Education Committee, 1954 and then all colleges were disaffiliated from Indian universities and affiliated to this university. This has grown as monolithic university with more than 150 thousand students in its 60 constituent campuses.

Nepal brought about the multi-university concept in 1983. As a result of this, the then Mahendra Sanskrita University, converted into Nepal Sanskrita University (NSU) after the Popular Movement 2006, came into existence in 1986. After the restoration of democracy in 1990, a number of universities: Kathmandu University (established in 1991), Purvanchal University (established in 1995), Pokhara University (established in 1997), Lumbini Boudh University (established in 2005), and deemed universities: National Academy of Medical Sciences (established in 2002), and B.P Koirala Institute of Health Sciences (established in 1993) came into existence. In addition to these universities, Nepal Government has announced to establish an Agriculture and Forest University in Rampur, Chitawan by merging the Institute of Forest and Institute of Agriculture being run under TU and an Open University. In the same vein, it has announced to establish the university in Far Western and Midwestern regions by amalgamating the constituent campuses of $\mathrm{TU}$ being run in these regions (GON, MOF 2007). Thus, four universities-the Agriculture and Forest University, Open University, Mid-Western University, Far-Western University, are in the pipeline. Af- 
ter 2010, foreign universities may be flooded in Nepal. Nepal Government has adopted the cost recovery policy since the Ninth Five Year Plan, 1997-2002 to reduce the burden of higher education on the national coffer (NPC 1998). It is desirable to investigate into the government expenditure in the higher education and analyze the private sector involvement in term of sharing of recurrent expenditures (REXP) of the university. So, this article attempts to analyze the financing of Nepal Government to the higher education in general and in particular the financing of capital expenditures (CEXP) as well as recurrent expenditures (REXP) of POKU.

\section{Data Source and Method of Analysis}

Primarily, data used in this paper have been extracted from the annual report of UGC. Secondly, financial data on POKU have been culled from the Account section, Centre Office, POKU. Thirdly, the data on the world scenario of higher education financing have been downloaded from the official website of UNESCO. UGC has yet to bring out its annual report for the FY 2006-2007. So, this paper does not cover the analysis of this particular year. Similarly, POKU launched academic programs only after 1999. So, this study has not gone beyond the fiscal year 1999. Lin-log model has been used to work out the growth rate of student enrolment, administrative grant and development grant (see Gujarati 2005). In addition, dependency ratio and independency ratio and cost recovery ratio have been used to analyze the financing pattern of higher education. The expenditures of UGC officeboth administrative and capital, and grants provided to public campuses are kept out of the scope of this paper.

\section{World Scenario of Higher Education Financing}

The financing of REXP by direct beneficiaries of higher education is the global trend of higher education financing. Only the question is on how much the direct beneficiaries should share REXP. The percentage of private sharing hinges on the subsidy of government to the operating costs. Government shifts the financial burden of operating cost of higher education by asking the higher education institutions to charge the fees to the direct beneficiaries (students, parents and sponsors) and lightens burden to the national exchequer. Nepal Government also is in the same vein.

As stated earlier, Nepal Government has adopted cost recovery approach in higher education. It is intending to finance the CEXP, transfer the REXP to the direct beneficiaries, and reduce the financial burden on its coffer. It has already opened the venue to private sector in higher education industry. So, private sector and community as a whole are sharing the CEXP of higher education also. But due to this policy of government and want of institutional arrangement for education loan, major section of the society is out of the access of higher education. Gross enrolment ratio (GER), which shows the ratio of enrolment on the total population, in tertiary education is 5 percent . This is far below 10 percent regional average ratio. GERs in Bhutan, India, China, Pakistan and Bangladesh are 3 percent, 11 percent, 13 percent, 4 percent and 6 percent respectively. In the case of developed countries, relative to our, it is very high. GER of the U.S.A, United Kingdome, Switzerland and Japan are 82 percent, 59 percent, 45 percent and 55 percent respectively. Even in South Africa, GER is far above the GER of our country (UNESCO 2007). 
Education budget of Nepal Government is satisfactory relative to the budget of neighboring countries. Education budget of Nepal Government hovers in the range of around 13 percent to 17 percent of the total budget during the study period (refer to Appendix 1). In neighboring countries also, it ranges from around 11 percent to 14 percent (refer to Appendix 2). In developed countries such as United Kingdom, the U.S.A and Switzerland also, the public expenditure on education hovers around the same range. For example, public expenditure of United Kingdom on education was 11.7 percent of the total public expenditure in 2004. Similarly, this was 9.8 percent in Japan in 2004. In term of gross domestic product (GDP) also, education budget of Nepal is satisfactory. In 2003, it was 3.4 percent. Percentages of education budget of neighboring countries in term of GDP are 5.6 percent, 2.5 percent, 3.8 percent, 2.3 percent and 1.9 percent in Bhutan, Bangladesh, India, Pakistan, and China respectively. In the case of developed countries such as the U.S.A, U.K., Switzerland and Japan, ratio of public expenditure on education is quite high relative to the South Asian countries (for comparison, refer to Appendix 2).

Higher education budget of Nepal Government for the observed years is in between around 9 percent and 19 percent of government budget on education. This ratio is lower than that of the neighboring countries (compare the ratios given in Appendix 2). In the latter years of the study period, investment in higher education is low. The GER and percentage of public expenditure on higher education of developed countries such as United Kingdom, the U.S.A and Switzerland are far greater than that of developing countries. Nepal has the least GER of tertiary education on one hand and on the other she does have very low ratio of budget allocated to higher education. This implies that major section of the society is out of the access of the higher education in Nepal.

\section{Government Financing of Higher Education in Nepal}

The then government established UGC in 1994 under the University Grants Commission Act, 1993 for equitable distribution of the grants received from government and donors to the universities being run in Nepal. Since then Nepal Government finances the higher education through UGC. Government financing is skewed to TU. More than 90 percent of the total administrative grant goes to $\mathrm{TU}$ and the rest goes to other four universities-KU, PU, NSU and POKU (refer to Appendix 4). It has admitted more than 96 percent of the student of higher education during the observed years (refer to Appendix 1). UGC is yet to chalk out the policy on how to distribute the grants among the universities. It does not have clear cut policy on the distribution of grants. Fundamentally, grants are provided on the basis of bare need of the universities. In the case of TU, per capita administrative grant is not more than twelve thousand. Tuition fees and other charges to students are nominal. So, always it comes across the financial problem even to finance its bare REXP.

Administrative grants across the universities and within the university are uneven. Except to the grant provided to KU, per capita administrative grant to TU is very low. KU being the first university established from the initiation of private sector receives less administrative and capital grants. Per capita administrative grant provided to KU is less than ten thousand during the study period. But per capita grants provided to NSU, PU and POKU are relatively high (see Appendix 5). Per capita administrative grants to these universities seem fallacious due to the low student number in their constituent colleges. The number of 
students in PU and POKU is less than 500 in all observed years and it is less than 2000 in NSU (see Appendix 1). These universities should have the strategy to increase the number of student to the optimum size to optimize their overhead expenditures in the years to come.

The annual growth rate of the student enrolment in tertiary education is 3.98 percent. But the growth rate in the administrative grant on the whole is 9.37 percent during the study period. Growth rate of administrative grant is in nominal term. Overall urban consumer price index during the study period on the average is around 4.09 (MOF 2003, 2005, 2007). At a glance, growth in overall public expenditure on tertiary education has superceded the growth rate in student number in real term also. But the grant per student is very small. Overall per capita administrative grants to universities are not more than Rs.12,000 during the study period.

\section{Table 1: Annual Growth in Student Enrolment, Overall Administrative Grant and Per Capita Administrative Grant}

\begin{tabular}{lccc}
\hline & Administrative Grant & Per Capita Grant & Student Enrolment \\
\hline All Universities & 9.37 & 5.23 & 3.98 \\
TU & 9.42 & 5.44 & 3.77 \\
KU & 9.42 & $(1.72)$ & 14.00 \\
PU & 2.22 & $(10.08)$ & 12.52 \\
POKU & 24.48 & $(8.44)$ & 33.64 \\
NSU & 8.11 & 1.41 & 3.04 \\
\hline
\end{tabular}

Source: Worked out from the data given in Appendix 1, 4 and 5 .

It is obvious that the grant provided to $\mathrm{TU}$ dominates the overall government expenditure on higher education. This is why growth rates in overall administrative grant and student enrolment are almost the same as in TU. The growth rates in the student number of TU and NSU are around 4 percent. Relative to the growth of higher secondary school and private campuses/colleges, growth in student numbers seems very low. TU has not added any constituent campus during the study period and has granted the affiliation to a number of private and community campuses during the study period (refer to Annul Reports of UGC for the detail of affiliated campuses). So, the student number growth in its constituent campuses is forceful and unplanned one.

Growth rates in administrative grant in newly established universities are positive but they are negative in per capital grant. This is because of the steep growth in student number and slow growth in the overall administrative grant. The growth rate in the overall administrative grant in PU seems relatively low and high in POKU. These rates give the fallacious impression about the resources provided to these universities. In the first year of the study period, the grant provided to PU is almost 6 times of the grant provided to POKU and it is almost one and half times in 2006. But the number of students is almost the same in both PU and POKU. So, the low growth rate in the administrative grant provided to PU and high growth in the grant to POKU do not imply the inequitable distribution of grant between these two universities. Per capita grant provided to these universities shows that PU is getting favor of UGC during the study period (see Appendix 5).

Financing of development expenditure is extremely in declining trend. This is because of the extreme effect of the development grant to TU. Major chunk of development 
grant has gone to TU during the study period. Development expenditure of universities especially TU is extremely large. It is due to the financing of the First Higher Education Project. But the data on the external financing are not available in the UGC's annual reports. So, it is not possible to break down the financing of CEXP of universities into external financing (EXTFIN) and internal financing (INTFIN). However, it is obvious that Nepal Government has provided the resources to newly established universities such as PU and POKU to finance their CEXP. It was not possible to collect the primary information on the financing pattern of each individual university in a short period. But the analysis of financing pattern of POKU has been done in the ensuing part of this paper.

\section{Financing of Recurrent Expenditure: A Case of POKU}

Cost recovery principle is the national policy of Nepal Government in financing the higher education. In this policy, students with paying capacity should pay for their higher education. An attempt has been made to look into the financing pattern of REXP of POKU incurred during the last $8 \mathrm{FYs}$. It is obvious that UGC and students are the fundamental sources of funds required to finance both REXP and CEXP of the university. UGC administrative grant is in increasing trend. But the ratio of administrative grant to REXP (external financing ratio) is decreasing year by year during the study period. In other words, dependency of university on government coffer is coming down year by year.

The lower external financing ratio implies the higher independency ratio measured by the ratio of INTFIN to REXP of the university. In general, cost recovery rate (RECRATE) also is increasing year by year during the study period. The increasing overall RECRATE, decreasing dependency ratio and increasing independency ratio show that university is gaining its operating financial strength. All these facts show that university is moving along the cost recovery path.

\section{Table 2: Financing of Recurrent Expenditures (in Rs.000)}

\begin{tabular}{|c|c|c|c|c|c|c|c|}
\hline Year & REXP. & EX & [FIN & & FIN & IN] & REV \\
\hline & & Amount & Percent & Amount & Percent & Amount & RECRATE \\
\hline 1999 & 3,376 & & & & & & \\
\hline & & 3060 & 90.63 & 316 & 9.37 & 1,023 & 30.30 \\
\hline 2000 & 9,849 & & & & & & \\
\hline & & 3100 & 31.48 & 6,749 & 68.52 & 5,589 & 56.74 \\
\hline 2001 & 14,554 & 7000 & 48.10 & 7,554 & 51.90 & 8,901 & 61.16 \\
\hline 2002 & 22,168 & 7200 & 32.48 & 14,968 & 67.52 & 17,155 & 77.38 \\
\hline 2003 & 32,983 & & & & & & \\
\hline 2004 & 29,358 & 7500 & 22.74 & 25,483 & 77.26 & 35,563 & 107.82 \\
\hline 2005 & 34,696 & 9200 & 31.34 & 20,158 & 68.66 & 23,051 & 78.52 \\
\hline 106 & 38,880 & 12510 & 36.06 & 22,186 & 63.94 & 31,477 & 90.72 \\
\hline & & 14418 & 37.08 & 24,462 & 62.92 & 32,431 & 83.41 \\
\hline
\end{tabular}

Source: Account Section, Centre Office, POKU. 
Though the overall RECRATE during the study period is not so bad. But the RECRATE in an individual faculty and cost centre is not so satisfactory. The Faculty of Humanities and Social Sciences has recovered the least cost from the students. Similarly, RECRATE of Faculty of Management also is not satisfactory. Except in 2006, its RECRATE is below 50 percent during the study period. Level of cost recovery in the Faculty of Science and Technology, to some extent, is satisfactory. Office of the Controller of Examinations also has not recovered the recurrent costs so far (see Appendix 6). The overall RECRATE is much higher than those of individual faculties. The reason behind this is the affiliation fee received from the affiliated colleges. The low RECRATE of individual faculties and high overall RECRATE imply that contribution of affiliated colleges to the university revenue is considerable amount during the study period.

Table 3: Financing of Capital Expenditures (in Rs.000)

\begin{tabular}{ccccccc}
\hline Year & CEXP. & \multicolumn{2}{c}{ EXTFIN } & \multicolumn{2}{c}{ INTFIN } & UGC Grants \\
\hline 1999 & 2,199 & Amount & Percent & Amount & Percent & \\
2000 & 3,386 & $2,199.00$ & 100.00 & - & - & 2,500 \\
2001 & 6,602 & $3,386.00$ & 100.00 & - & - & 5,000 \\
2002 & 12,985 & $6,000.00$ & 90.88 & 602.00 & 9.12 & 6,000 \\
2003 & 23,147 & $9,000.00$ & 69.31 & $3,985.00$ & 30.69 & 9,000 \\
2004 & 22,337 & $19,100.00$ & 82.52 & $4,047.00$ & 17.48 & 19,100 \\
2005 & 19,771 & $19,100.00$ & 85.51 & $3,237.00$ & 14.49 & 19,100 \\
2006 & 11,309 & $18,800.00$ & 95.09 & 971.00 & 4.91 & 18,800 \\
& & $11,309.00$ & 100.00 & - & - & 17,538 \\
\hline
\end{tabular}

Source: Account Section, Centre Office, POKU.

There are two major sources of financing of development expenditures: development grants and surplus of internal revenue. Sometime, university can use deposit such as student security deposit, performance deposit of contractor to bridge the development expenditure with development grant. In the same token, university may not be able to launch the infrastructure development project in time. This may result in the surplus or freeze of the funds released for development works. Such surplus may affect adversely the budget allocation of government to the university in the year to come. In most of the years, POKU has mobilized 100 percent of development grant provided by UGC. But in some years, it has not been able to mobilize the funds provided for development works. Development grant has dominant role in CEXP financing of the university. In some years, it has used dismal amount of surplus of INTREV to finance the CEXP. UGC has provided in total Rs.97,038,000 development grants to the university during the study period and total CEXP during the 
study period is Rs.101,735,000. Thus, around 95 percent of CEXP has been financed by the funds received from national coffer. This implies that Nepal Government has fully supported POKU to build up the physical infrastructure of the university. The preamble of university states that university will be operated through the maximum participation of private sector. But the financing pattern of CEXP does not bolster this statement in reality.

\section{Summing up}

The government budget to education, in relative term measured by the ratio of education budget to total national budget, is not so poor in relation to the budget of the neighboring and other developed countries. But the government expenditure on higher education is poor in comparison to other countries-both developed and developing countries. Further, the analysis of growth in administrative grants to different universities, and student enrollment implies that UGC does not have clear cut policy for providing the administrative and capital grants to the universities.

Financial dependency of POKU on national exchequer is decreasing year by year. But, on the whole, RECRATE of each individual faculty is not satisfactory. Low level of RECRATE of individual programs and increasing overall RECRATE of the university imply that affiliated colleges are contributing to generate the revenue of POKU. This suggests that POKU does need to align its programs in the line of the principle-students with paying capacity should pay for REXP and cross subsidize those with poor paying capacity. Further, the overall RECRATE suggests that POKU can not generate the surplus to finance the CEXP of the university. So, POKU should manage the funds from national exchequer or from development agencies and donors to build up the required academic and physical infrastructure of the university.

\section{ACKNOWLEDGEMENTS}

I would like to acknowledge Mr. Yadav Bdr. Thapa, Acting Account Controller, POKU and Rabindra Subedi, Accountant, POKU for their kind cooperation to cull the financial data from the books of accounts. Similarly, I would like to acknowledge the UGC for providing its annual reports. Finally, I would like to acknowledge the other institutions especially, UNESCO, Save the Children, Norway and Nepal Government, Ministry of Education and Sports for making the data on the education available publicly.

\section{Appendix 1: Student Enrolment in Different Universities}

$\begin{array}{ccccccc}\text { Year } & \text { TU } & \text { KU } & \text { PU } & \text { POKU } & \text { NSU } & \text { Total } \\ 1999 & 93,396 & 982 & 71 & 0 & 1,212 & 95,661 \\ 2000 & 127,355 & 1,284 & 255 & 67 & 1,784 & 130,745 \\ 2001 & 146,749 & 1,497 & 214 & 128 & 1,606 & 150,194 \\ 2002 & 142,308 & 1,783 & 240 & 95 & 1,697 & 146,123 \\ 2003 & 140,412 & 1,808 & 285 & 185 & 1,144 & 143,834 \\ 2004 & 123,403 & 2,239 & 306 & 285 & 1,480 & 127,713 \\ 2005 & 132,779 & 2,476 & 222 & 285 & 2,319 & 138,081 \\ 2006 & 153,126 & 2,476 & 272 & 408 & 1,584 & 157,866\end{array}$

Source: UGC, Annual Reports, (1988/99 through 2005/66). 


\section{Appendix 2: Selected Higher Education Indicators.}

Country GER (in\%) Public Expenditure on Education (PEOE) HEDB as \% of PEOE As \% of As \% of Total Government

\begin{tabular}{lclll} 
& GDP & \multicolumn{2}{c}{ Expenditure } & \\
\hline 1. Bhutan & 03 & $5.6(2001)$ & $12.9(2001)$ & 20.00 \\
2. Nepal & 05 & $3.4(2003)$ & $14.9(2003)^{*}$ & $10.21(2003)^{*}$ \\
3. India & 11 & $3.8(2004)$ & $10.7(2003)$ & 18.00 \\
4. Pakistan & 04 & 2.3 & 10.9 & NA \\
5. China & 13 & $1.9(1999)$ & $13.0(1999)$ & 21.0 \\
6. South Africa & 15 & 5.3 & 17.9 & 16.0 \\
7. U.K & 59 & $5.4(2004)$ & $11.7(2004)$ & 20 \\
8. The U.S.A. & 82 & $5.6(2004)$ & $14.4(2004)$ & NA \\
9. Japan & 55 & $3.7(2004)$ & $9.8(2004)$ & 14.0 \\
10. Switzerland & 45 & $6.0(2004)$ & $13.0(2003)$ & $28(2004)$ \\
11. Bangladesh & 06 & 2.5 & 14.2 & 14.2 \\
12. Ethiopia & 03 & $6.0(2006)$ & $17.5(2006)$ & 17.0 \\
\hline
\end{tabular}

Source: UNESCO, Institute for Statistics, UIS Statistics in Brief. 2007. UGC, Annual Report, 2002-2003.

Appendix 3: Annual Budget of Nepal Government on Education and Higher Education (in Rs.000)

\begin{tabular}{cccccccc}
\hline Year & TNGB & \multicolumn{2}{c}{ TBED } & \multicolumn{2}{c}{ HEDB } & \multicolumn{2}{c}{ University Budget } \\
& & Amount & Percent & Amount & Percent & Amount* & Percent \\
\hline 2000 & 77,238 & 10,176 & 13.17 & 1,720 & 16.90 & 1,676 & 16.47 \\
2001 & 91,621 & 11,750 & 12.82 & 2,202 & 18.74 & 1,928 & 16.41 \\
2002 & 99,792 & 14,073 & 14.10 & 1,680 & 11.94 & 1,672 & 11.88 \\
2003 & 96,125 & $14,402 \backslash$ & 14.98 & 1,471 & 10.21 & 1,410 & 9.79 \\
2004 & 102,400 & 15,613 & 15.25 & 1,468 & 9.40 & 1,627 & 10.42 \\
2005 & 111,690 & 18,060 & 16.17 & 1,678 & 9.29 & 1,750 & 9.69 \\
2006 & 126,885 & 21,250 & 16.75 & 1,974 & 9.29 & 1,908 & 8.98
\end{tabular}

Source: GON, MOF. Red Book 2007-2008.

* Compiled from UGC, Annual Reports.

Appendix 4: Administrative Grants to Universities (in Rs.000)

\begin{tabular}{ccccccc}
\hline Year & TU & KU & PU & POKU & NSU & Total \\
\hline 1999 & 825,657 & 6,900 & 17,400 & 3,060 & 62,112 & 915,129 \\
2000 & 857,728 & 6,908 & 17,411 & 3,268 & 64,718 & 950,033 \\
2001 & $1,223,150$ & 7,100 & 17,600 & 7,000 & 87,210 & $1,342,060$ \\
2002 & $1,340,000$ & 7,100 & 17,600 & 7,200 & 95,300 & $1,467,200$ \\
2003 & $1,210,000$ & 7,200 & 17,700 & 7,500 & 88,000 & $1,330,400$ \\
2004 & $1,388,300$ & 7,600 & 18,200 & 9,200 & 91,000 & $1,514,300$ \\
2005 & $1,496,261$ & 7,956 & 19,468 & 12,510 & 106,007 & $1,642,202$ \\
2006 & $1,577,402$ & 23,649 & 20,664 & 14,418 & 110,583 & $1,746,716$ \\
\hline
\end{tabular}

Sources: UGC, Annual Reports, (1988/99 through 2005/66). 
Appendix 5: Per Capita Administrative Grants (in Rs.000)

\begin{tabular}{ccccccc}
\hline YR & TU & KU & PU & POKU & NSU & Total \\
\hline 1999 & 8.84 & 7.03 & 245.07 & - & 60.36 & 9.12 \\
2000 & 6.73 & 5.38 & 68.28 & 48.78 & 53.40 & 9.93 \\
2001 & 8.33 & 4.74 & 82.24 & 54.69 & 48.88 & 10.26 \\
2002 & 9.42 & 3.98 & 73.33 & 75.79 & 59.34 & 9.77 \\
2003 & 8.62 & 3.98 & 62.11 & 40.54 & 51.86 & 9.10 \\
2004 & 11.25 & 3.39 & 59.48 & 32.28 & 79.55 & 10.53 \\
2005 & 11.27 & 3.21 & 87.69 & 43.90 & 71.63 & 12.86 \\
2006 & 10.30 & 9.55 & 75.97 & 35.34 & 47.69 & 12.65 \\
\hline
\end{tabular}

Source: Based on the data given in Appendix 1 and Appendix 4.

$\begin{aligned} & \text { Appendix 6: Cost Recovery Rate of Individual Faculty and Office of the Controller of } \\
& \text { Examination of POKU }\end{aligned}$
\begin{tabular}{ccccc}
\hline Year & Management & $\begin{array}{l}\text { Science and } \\
\text { Technology }\end{array}$ & Humanities & $\begin{array}{c}\text { Office of the Controller } \\
\text { of Examinations }\end{array}$ \\
\hline 1999 & - & - & - & - \\
2000 & 28.16 & - & - & 31.90 \\
2001 & 31.58 & - & - & 54.32 \\
2002 & 36.23 & - & - & 66.76 \\
2003 & 46.44 & 65.97 & 17.64 & 86.41 \\
2004 & 43.35 & 53.04 & 27.12 & 77.53 \\
2005 & 41.98 & 51.04 & 27.16 & 98.22 \\
2006 & 52.75 & 78.47 & 33.30 & 91.20 \\
2007 & 46.92 & 75.21 & NA
\end{tabular}

Source: Worked out on the basis of data provided by Account Section, Centre Office, POKU.

\section{REFERENCES}

All Nepal Education Committee. 1961. Report (text in Nepali). Kathmandu: HMG/Nepal, Department of Education. August 26, 2004 http://202.52.206.7/edulaw/nepali/files/pdf/Report/ All Nepal Education Committees Report 2018.pdf.

Government of Nepal, Ministry of Finance (GON, MOF) . 2007. Budget Speech of Fiscal Year 2007-08. Kathmandu: Ministry of Finance.

_ _ _ 2007. Economic Survey, 2006/2007. Kathmandu: MOF.

_ — - 2005. Economic Survey, 2004/2005. Kathmandu: MOF.

— _ - 2003. Economic Survey, 2002/2003. Kathmandu: MOF.

Gujarati, Damodar N. 2005. Basics Econometrics. 4rth ed. New Delhi: TataMcGraw-Hill Publishing Company Limited.

HMG/Nepal, National Planning Commission. 1998. Ninth Plan, 1997-2002. Kathmandu: National Planning Commission.

UNESCO Institute for Statistics. 2007. UIS STATISTICS IN BRIEF. Dec. 22, 2007.

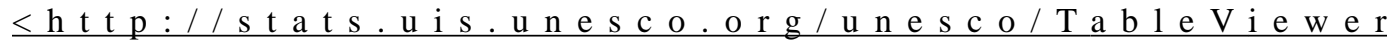
document.aspx ?ReportId=121\&IF Language=eng\&BR Country=5240\&BR Region=4053 